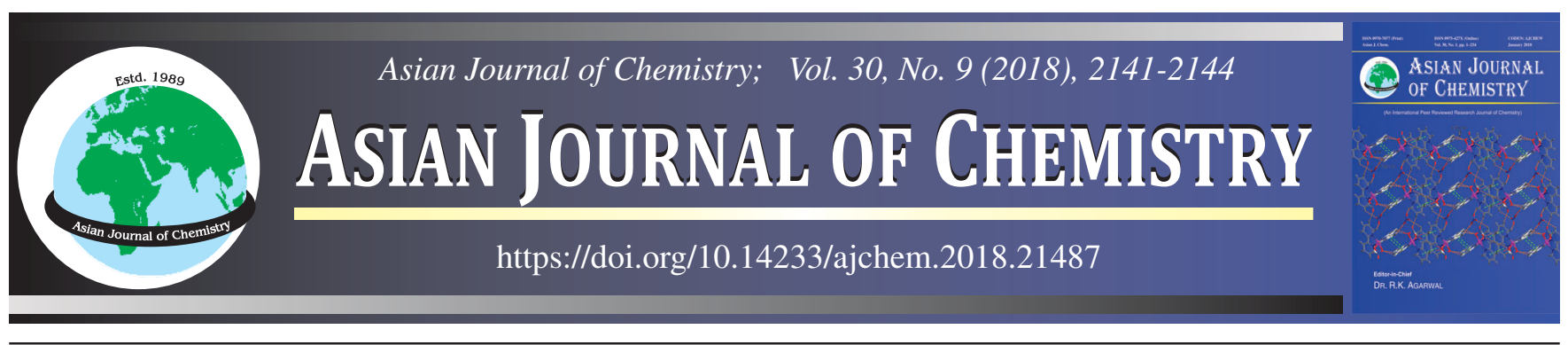

\title{
Sulfadiazine Guanidyl Derivatives: Synthesis, Characterization and Docking Studies for Potential Antituberculosis Agents
}

\author{
Mahesh Bhat ${ }^{1, *}$, B.C. GANAVI ${ }^{1}$, B.K. SAgaR ${ }^{2}$ and E. VIJAY SheKAR ${ }^{1}$
}

${ }^{1}$ P.G. Department of Chemistry, J.S.S. College for Women, Saraswathipuram, Mysore-570 009, India

${ }^{2}$ Department of Studies in Chemistry, University of Mysore, Manasagangothri, Mysore-570 006, India

*Corresponding author: E-mail: maheshbhat08@gmail.com

Received: 29 May 2018;

Accepted: 11 June 2018;

Published online: 31 July 2018;

AJC-19033

| Due to the wide range of pharmacological and biological activities, guanidine considered as one of the attractive pharmacophores. The presence of $-\mathrm{CN}_{3}$ group in guanidine compounds makes them to have efficient affinity towards various substituents with wide range of biochemical activities. In the present study, novel sulfadiazine guanidyl derivatives were synthesized and characterized by FT-IR, LC-MS and NMR spectral studies. The synthesized compounds were screened for antituberculosis activity and molecular docking study with InhA proteins was carried out. It was found that the compounds with electron donating groups exhibited superior activity.

Keywords: Guanidines, Antituberculosis activity, Docking studies, InhA proteins.

L - - - -

\section{INTRODUCTION}

The compound containing - $\mathrm{CN}_{3}$ group are called as guanidine. Guanidine is similar to the structure of imide urea, So the chemistry and properties of guanidines are resembles with imide urea [1]. The guanidine group is found in wide variety of both natural and synthetic compounds. The presence of guanidine functionality enhances activity and also helpful to interact with functional groups of enzyme or receptors, because of these properties, the study of guanidine derivatives becomes more important [2]. The guanidine sub-unit exhibits hydrogen bonding, this also responsible for the enhanced activity [3]. In this way, guanidine compounds are useful pharmacophores in medicines and wide applications in synthetic chemistry, organic materials, sensors, advanced synthetic molecular recognition devices and phase transfer catalyst [4-6]. Guanidines used for the curing the diabetic syndrome and biguanidine are characteristics properties towards the type two mellitus diabetic therapy.

Similar to thiourea derivatives, guanidines exhibited the potent antimicrobial agents. Kamoda et al. [7] synthesized mono substituted aryl ester derivatives of guanidine (TG44), an anti $H$. pylori agent. Recently benzothiazole guanidines were synthesized with methyl and 1-[2-(substituted benzothia- zole)-1,3-diethyl-4-aryl substituent's and screened for antiinflammatory and analgesic activities [7]. In our previous works, we found that guanidinyl benzothiazole derivatives also act as antimicrobial, antioxidant, antitubercular agents, etc. [8-10].

Sulfadiazine belongs to sulfonamide groups, used as antibacterial agent for curing the mild-to-moderate infections of the sensitive organisms [11]. Like other sulfonamides, sulfadiazine is used for the treatment for isosyncratic liver injury [12]. Herein, we reported the synthesis of sulfadiazine derivatives, which posses an interesting profile of antioxidant activity.

In this investigation, we have synthesized a series of sulfadiazine guanidinyl derivative through multi step reaction, initially by condensation then finally reaction with substituted aniline with good yields. Further, the synthesized compounds were characterized by LC-MS, IR and NMR. The newly synthesized derivatives were evaluated for their antioxidant potential towards DPPH free radical scavenging activity and also comparative studies were done.

\section{EXPERIMENTAL}

Synthesis of benzyolisothiocyanates (Step-1): A solution of benzoyl chloride $(0.014 \mathrm{~mol})$ in acetone $(20 \mathrm{~mL})$ was taken in a $100 \mathrm{~mL}$ round bottom flask and to that suspension of

This is an open access journal, and articles are distributed under the terms of the Creative Commons Attribution-NonCommercial 4.0 International (CC BY-NC 4.0) License, which allows others to copy and redistribute the material in any medium or format, remix, transform, and build upon the material, as long as appropriate credit is given and the new creations are licensed under the identical terms. 
ammonium thiocyanate $(0.018 \mathrm{~mol})$ in acetone $(20 \mathrm{~mL})$ was added portionwise and refluxed for $0.5 \mathrm{~h}$. After yellow solid appeared, the reaction mixture was cooled to room temperature.

Synthesis of thiourea derivative of sulfadiazine (Step2): Sulfadiazine $(0.014 \mathrm{~mol})$ in acetone $(20 \mathrm{~mL})$ was added dropwise to Step-1 product and heated to reflux for $3 \mathrm{~h}$. After completion of the reaction, the mixture was poured into crushed ice and filtered the solid precipitate and dried. The crude material was purified by recrystallization from ethanol.

Synthesis of sulfadiazine gunidinyl derivatives (Step-3): All guanidines were synthesized by the reported method [10]. The thiourea of sulfadiazine was mixed with different substituted anilines in DMF in equimolar ratios, with two equivalents of triethylamine. The temperature was maintained below $5^{\circ} \mathrm{C}$ using an ice bath, one equivalent of mercuric chloride was added to the reaction mixture with vigorous stirring. The ice bath was removed after $0.5 \mathrm{~h}$ and the mixture was stirred overnight. Progress of the reaction was monitored by TLC until completion. Chloroform $(20 \mathrm{~mL})$ was added to the reaction mixture and the suspension was filtered through a cillate bed to remove $\mathrm{HgS}$. The solvent from the filtrate was evaporated under reduced pressure and the residue was redissolved in $\mathrm{CH}_{2} \mathrm{Cl}_{2}(20 \mathrm{~mL})$, washed with water $(4 \times 50 \mathrm{~mL})$ and the combined organic phase washed with brine $(20 \mathrm{~mL})$, dried over anhydrous $\mathrm{Na}_{2} \mathrm{SO}_{4}$. The solvent was evaporated and the residue was purified by column chromatography and finally recrystallized in ethanol [11] (Scheme-I).

N-[(2-Nitrophenylamino)(4-(N-pyrimidin-2-ylsulfamoyl)phenylamino)methylene]benzamide (1): Yield: 87.7 $\%$, m.f. $\mathrm{C}_{23} \mathrm{H}_{19} \mathrm{~N}_{7} \mathrm{O}_{3} \mathrm{~S}$, m.w.: 517.12, off-white solid, m.p. 175$176^{\circ} \mathrm{C}$. Elemental analysis \% Calcd. (found): C, 55.70 (56.35); H, 3.70 (3.65); N, 18.95 (18.46). FT-IR (KBr, $\left.v_{\max }, \mathrm{cm}^{-1}\right): 3280$ (-NH), 3142 (SO-NH), 3055 (Ar-C-H), $1710(\mathrm{C}=\mathrm{O}), 1617,1340$ $\left(\mathrm{NO}_{2}\right), 1540$ (Ar C=C), 1347, 1305 (C-C), $1340(\mathrm{C}-\mathrm{N}), 1355$, 1165 ( $\underline{\mathrm{SO}}-\mathrm{NH}) .{ }^{1} \mathrm{H}$ NMR (400 MHz, DMSO-d $)$ ): $\delta 10.82(\mathrm{~s}$, 1H), 9.64 (s, 1H), 8.63- 8.61 (d, $J=9.6 \mathrm{~Hz}, 2 \mathrm{H}), 8.23-8.21$ (m, 3H), 8.17-8.15 (d, $J=7.2 \mathrm{~Hz}, 2 \mathrm{H}), 7.96-7.94$ (t, $J=7.6$ $\mathrm{Hz}, 14.2 \mathrm{~Hz}, 2 \mathrm{H}), 7.82$ (s, 1H), 7.64-7.62 (d, $J=8.8 \mathrm{~Hz}, 2 \mathrm{H})$, 7.53-7.51 (d, $J=8.0 \mathrm{~Hz}, 1 \mathrm{H}), 7.46-7.43(\mathrm{t}, J=4.8,13.6 \mathrm{~Hz}$, 2H), 7.23-6.20 (m, 2H), 4.08 (s, 1H). ${ }^{13} \mathrm{C} \mathrm{NMR} \mathrm{(100} \mathrm{MHz,}$ $\left.\mathrm{CDCl}_{3}\right): \delta 175.92,169.3,158.2,157.8,141.6,139.3,137.5$, 135.4, 134.5, 131.6, 130.2, 129.9, 129.2, 125.9, 119.6, 115.3, 113.1, 112.7. LC-MS Found: $m / z 518.23$ for $[\mathrm{M}+1]^{+}$peak and calculated 517.12.

N-[(4-nitro phenylamino)(4-(N-pyrimidin-2-ylsulfamoyl)phenylamino)methylene]benzamide (2): Yield: $84.1 \%$, m.f.:
$\mathrm{C}_{22} \mathrm{H}_{19} \mathrm{~N}_{7} \mathrm{O}_{3} \mathrm{~S}$, m.w.: 517.12, Yellow solid, m.p. $187-188^{\circ} \mathrm{C}$. Elemental analysis \% Calcd. (found): C, 55.70 (56.43); H, 3.70 (3.58); N, 18.95 (18.02). FT-IR (KBr, $\left.v_{\max }, \mathrm{cm}^{-1}\right): 3310(-\mathrm{NH})$, 3148 (SO-NH), 3052 (Ar-C-H), $1725(\mathrm{C}=\mathrm{O}), 1610,13420\left(\mathrm{NO}_{2}\right)$, 1525 (Ar C=C), 1360, 1318 (C-C), $1335(\mathrm{C}-\mathrm{N}), 1350,1145$ (으NH). ${ }^{1} \mathrm{H}$ NMR (400 MHz, DMSO- $\left.d_{6}\right): \delta 11.22(\mathrm{~s}, 1 \mathrm{H}), 9.87(\mathrm{~s}$, $1 \mathrm{H}), 8.42-8.40$ (t, 1H), 7.96-7.94 (d, $J=8.4 \mathrm{~Hz}, 1 \mathrm{H}), 7.85-7.81$ $(\mathrm{m}, 3 \mathrm{H}), 7.82-7.80(\mathrm{~d}, J=7.6 \mathrm{~Hz}, 2 \mathrm{H}), 7.65-7.63(\mathrm{~d}, J=8.8 \mathrm{~Hz}$, 2H), 7.59-7.57 (d, J=8.4 Hz, 2H), 7.46-7.43 (t, 2H), 7.32-6.29 (m, 2H), $4.16(\mathrm{~s}, 1 \mathrm{H}) .{ }^{13} \mathrm{C} \mathrm{NMR}\left(100 \mathrm{MHz}, \mathrm{CDCl}_{3}\right): \delta 174.5$, 170.2, 159.40, 157.6, 142.8, 140.3, 138.6, 136.7, 135.2, 132.4, 131.8, 130.1, 129.8, 126.4, 120.3, 117.5, 115.9, 113.4. LCMS Found: $m / z 518.3$ for $[\mathrm{M}+1]^{+}$peak and calculated 517.3.

$\mathrm{N}$-[(phenylamino)(4-(N-pyrimidin-2-ylsulfamoyl) phenylamino)methylene]benzamide (3): Yeild: $89.6 \%$, m.f.: $\mathrm{C}_{23} \mathrm{H}_{20} \mathrm{~N}_{6} \mathrm{O}_{3} \mathrm{~S}$, m.w.: 472, off white solid, m.p. $117-118{ }^{\circ} \mathrm{C}$. Elemental analysis \% Calcd. (found): C, 61.00 (60.52); H, 4.27 (4.32); N, 17.79 (17.58). FT-IR (KBr, $\left.v_{\max }, \mathrm{cm}^{-1}\right): 3270(-\mathrm{NH})$, 3125 (SO-NH), 3042 (Ar-C-H), $1718(\mathrm{C}=\mathrm{O}), 1608,1320$ $\left(\mathrm{NO}_{2}\right), 1564(\mathrm{Ar} \mathrm{C}=\mathrm{C}), 1340,1310(\mathrm{C}-\mathrm{C}), 1348(\mathrm{C}-\mathrm{N}), 1372$, 1160 ( $\underline{\text { SO-NH). }}{ }^{1} \mathrm{H}$ NMR (400 MHz, DMSO-d $): \delta 10.62(\mathrm{~s}, 1 \mathrm{H})$, 9.92 (s, 1H), 8.34- 8.32 (t, 1H), 8.10-7.98 (d, $J=8.0 \mathrm{~Hz}, 1 \mathrm{H})$, 8.96-8.94 ( $J=7.2 \mathrm{~Hz}, 2 \mathrm{H}), 7.93-7.91(\mathrm{~m}, 3 \mathrm{H}), 7.87-7.85(\mathrm{~d}, J$ $=9.6 \mathrm{~Hz}, 2 \mathrm{H}), 7.72-7.70(\mathrm{~d}, J=7.6 \mathrm{~Hz}, 2 \mathrm{H}), 7.64-7.62(\mathrm{~d}, J=$ 8.0 Hz, 2H), 7.43- 7.41 (t, 2H), 7.37-6.35 (m, 2H), 4.12 (s, 1H). ${ }^{13} \mathrm{C} \mathrm{NMR}\left(100 \mathrm{MHz}, \mathrm{CDCl}_{3}\right): \delta 172.3,168.7,157.5,152.9,141.6$, 141.2, 139.8, 137.1, 133.5, 132.2, 131.4, 130.0, 128.4, 127.7, 121.5, 116.2, 114.4, 112.3. LC-MS Found: $m / z 473.13$ for $[\mathrm{M}+1]^{+}$peak and calculated 472.15 .

N-[(3,4-Dimethylphenylamino)(4-(N-pyrimidin-2-ylsulfamoyl) phenylamino)methylene] benzamide (4): Yield: $85.8 \%$, m.f.: $\mathrm{C}_{26} \mathrm{H}_{20} \mathrm{~N}_{6} \mathrm{O}_{3}$ S, m.w.: 500, brown solid, m.p. 190$192{ }^{\circ} \mathrm{C}$. Elemental analysis \% Calcd. (found): C, 62.38 (61.95); H, 4.83 (4.89); N, 16.79 (16.27). FT-IR (KBr, $\left.v_{\max }, \mathrm{cm}^{-1}\right): 3218$ (-NH), 3145 (SO-NH), $3110(\mathrm{Ar}-\mathrm{C}-\mathrm{H}), 2983\left(\mathrm{CH}_{3}\right), 1690(\mathrm{C}=\mathrm{O})$, 1620, $1335\left(\mathrm{NO}_{2}\right), 1535$ (Ar C=C), 1350, $1310(\mathrm{C}-\mathrm{C}), 1343(\mathrm{C}-\mathrm{N})$,

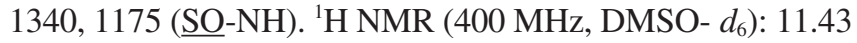
(s, 1H), 9.92 (s, 1H), 8.48-8.46 (t, 1H), 7.98-7.93 (s, 1H), 7.92 (s, 3H), $7.66(\mathrm{~s}, 1 \mathrm{H}), 7.59-7.57(\mathrm{~d}, J=8.0 \mathrm{~Hz}, 2 \mathrm{H}), 7.51-7.50$ $(\mathrm{d}, J=5.6 \mathrm{~Hz}, 1 \mathrm{H}), 7.43-7.39$ (t, 2H), 7.18-6.97 (m, 2H), 4.02 (s, 1H), 3.03 (s, 3H), 2.86 (s, 3H). ${ }^{13} \mathrm{C} \mathrm{NMR} \mathrm{(100} \mathrm{MHz,} \mathrm{CDCl}_{3}$ ): $\delta 175.5,171.2,158.5,156.3,144.2,141.2,139.4,136.1,134.8$, 131.9, 131.6, 129.9, 129.4, 125.4, 121.7, 118.2, 115.4, 113.4, 38.27, 20.83. LC-MS Found: $m / z 501.01$ for $[\mathrm{M}+1]^{+}$peak and calculated 500 .

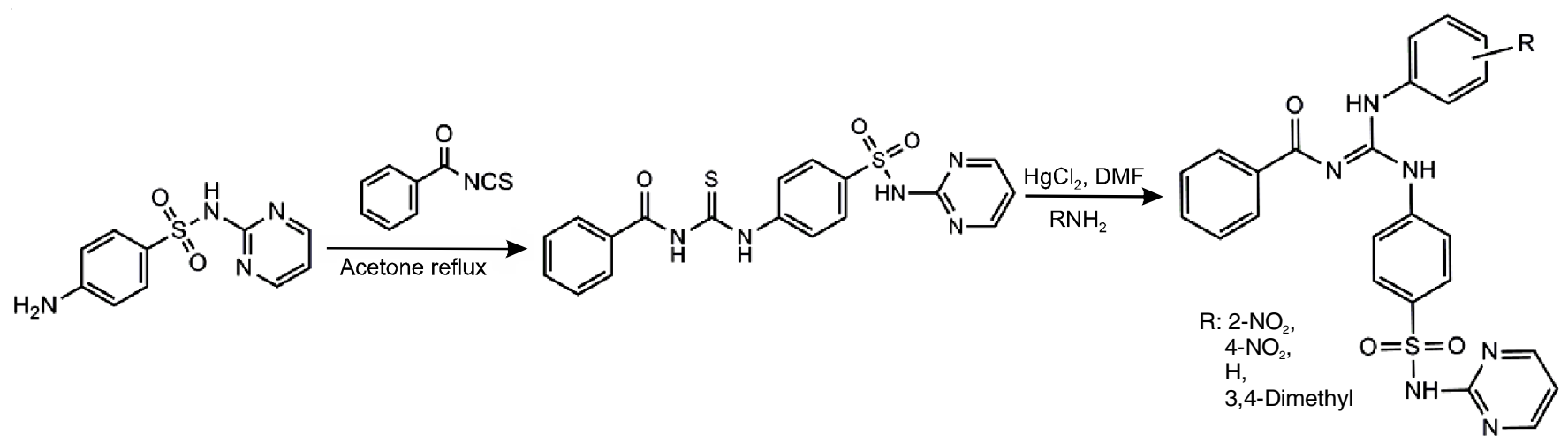

Scheme-I: Synthesis of sulfadiazine gunidinyl derivatives 
Antituberculosis activity: The tuberculosis disease is caused by Mycobacterium tuberculosis and it mainly causes the lungs and synthesized Sulfadiazene derivatives was checked against M. tuberculosis (H37Rv strain): ATCC No. 27294 by in vitro micro-plate Alamar Blue assay method [13]. The antimycobacterial activity of compounds was screened by microplate Alamar Blue assay (MABA) for M. tuberculosis $100 \mu \mathrm{g} / \mathrm{mL}$ and serial half fold solutions of test compounds were prepared. In 96 well micro-titre plate serial two-fold dilutions of synthesized compounds were added to each of the wells $(100 \mu \mathrm{g} / \mathrm{mL}$ to $0.2 \mu \mathrm{g} / \mathrm{mL}$ ) and to that $100 \mu \mathrm{L}$ of Middlebrook $7 \mathrm{H} 9$ broth was added. After addition of the test solutions, plates were covered with parafilm and incubated at $37^{\circ} \mathrm{C}$ for 5 days. After completion of the incubation, freshly prepared $25 \mu \mathrm{L}$ of $1: 1$ mixture Alamar Blue reagent and $10 \%$ Tween 80 was added to each of the wells and once again incubated for $24 \mathrm{~h}$ at $37^{\circ} \mathrm{C}$. The plates were cooled to room temperature. Appearance of the blue color in the wells indicated as no bacterial growth and compound was sensitive to that concentration. The pink colour appearance in the wells indicated the resistance of bacteria, which represented absence of activity. MIC of the compound was defined as the minimum concentration of drug, which prevents the colour change from blue to pink.

Antioxidant activity: Free radicles scavenging ability by DPPH radical assay: DPPH scavenging activity of isolated compound was determined as previously reported. Various concentration of tested sample in aliquot of $100 \mu \mathrm{L}$ were mixed with $100 \mu \mathrm{L}$ of $40 \mu \mathrm{M}$ methonolic solution of DPPH in 96well micro-titer plate the decrease in absorbance at $517 \mathrm{~nm}$ was recorded after the incubation of $15 \mathrm{~min}$ at room temperature. The absorbance of DPPH solution with only methanol and without the sample used as the control. The BHT was used as standared to compare the activity. The assay was carried out in triplicate. The percentage inhibition of the DPPH radical by the sample was calculated according to the formula [14].

$$
\text { Inhibition }(\%)=\frac{\mathrm{A}_{\mathrm{C}}-\mathrm{A}_{\mathrm{S}}}{\mathrm{A}_{\mathrm{C}}} \times 100
$$

where $A_{C}$ is the absorbance of control and $A_{S}$ is the absorbance of sample at $15 \mathrm{~min}$

Molecular docking: Molecular docking studies were performed with the help of Schrodinger software suite, maestro 9.35 version (2011). The structure of the molecules was drawn in Chem ISIS draw and saved as mole file and used for the determination of ability of the compound to interact with selected protein. The 3D crystallographic structure of protein enoyl acyl carrier reductase (InhA) of M. tuberculosis (PDB:ID: 1ZID) was retrieved from protein data bank (www.rch.org/pdb). The protein structure were pre-processed and refined by protein preparation wizard. Further, it was minimized by OPLF-2005 (optimized potential for liquid simulations) force field to get the 0.3 Aoroot mean square deviations (RMSD). Lig prep program by OPLS-2005 force field was used for the optimization of selected ligand for generation of lowest energy state.The molecule docking studies of ligands and protein were determined by GLIDE .The activity was ranked on the basis of docking score. Those docking scores depend on how the ligands fill the target protein [15].

\section{RESULTS AND DISCUSSION}

Four molecules of new sulfadiazine gunidinyl derivatives were synthesized. In first step, benzoyl chloride reacted with potassium thiocyanate in acetone, on refluxing white precipitate was formed. By cooling reaction mixture and added solution of 4-amino-N-pyrimidin-2-ylbenzene sulfonamide in acetone was added drop-wise. In second step, equimolar ratios of sulfadiazine thiourea derivative and different amines were taken in DMF and two equivalents of triethylamine and one equivalent of $\mathrm{HgCl}_{2}$ was added and stirred at overnight at room temperature. So in this way, sulfadiazine gunidinyl derivatives were synthesized by efficient way with benzyol thiourea and substituted aniline in the presence of $\mathrm{HgCl}_{2}$ and triethylamine. The synthesized compounds were characterized by ${ }^{1} \mathrm{H}$ NMR and LC-MS spectral analysis.

Antituberculosis activity: All the tested compounds showed antituberculosis activity and minimum inhibition concentrations are in between 100 to $12.5 \mu \mathrm{g} / \mathrm{mL}$. In the series of synthesized compound, 3,4-dimethyl substituted compound exhibited enhanced activity in the series. The activity is lower for nitro substitutents, however activity has gradually increase for without substitution to 3,5 dimethyl substitution. It is confirmed that the presence of electron donating increases with electron donating group and decreases with electron withdrawing group.

Molecular docking studies: The molecular docking study of targeted benzothiazole derivatives with enoyl acyl carrier reductase (InhA) (PDB ID-1ZID) of M. tuberculosis was carried out to interpret the molecular interactions with proteins. InhA is key enzyme, which is involved in the type II fatty acid biosynthesis pathway of M. tubecrulosis. InhA inhibition blocks the biosynthesis of mycolic acid, which is lipid involved in the formation of cell wall of Mycobacterium (Fig. 1). Here, compounds showed the remarkable docking score -5.944 to -5.023 , which can be compared with the standard drug pyrazinamide with -5.549 and ciprofloxacin-5.3 as docking scores. The docking scores of synthesized compounds with InhA are shown in Table-1.

\begin{tabular}{cccc}
\multicolumn{4}{c}{ TABLE-1 } \\
\multicolumn{4}{c}{ ANTI-TB AND DOCKING STUDY OF } \\
THE SYNTHESIZED COMPOUND \\
\hline Compound No. & $\mathrm{R}$ & $\mathrm{MIC}(\mu \mathrm{g} / \mathrm{mL})$ & Docking score \\
\hline 1 & $2-\mathrm{NO}_{2}$ & 100 & -5.944 \\
2 & $4-\mathrm{NO}_{2}$ & 50 & -5.148 \\
3 & $\mathrm{H}$ & 25 & -5.032 \\
4 & $3,4-\left(\mathrm{CH}_{3}\right)_{2}$ & 12.5 & -5.032 \\
Pyrazinamide & & 3.12 & -5.549 \\
\hline
\end{tabular}

Antioxidant activity: In guanidine derivatives, guanidine unit had capacity to form hydrogen bond. In addition to this, synthesized compounds containing $-4 \mathrm{NO}_{2},-2 \mathrm{NO}_{2},-\mathrm{H},-3,4$ dimethyl groups, which are capable of releasing $\mathrm{H}^{+}$ion and form anionic moiety, which are responsible for the scavenging action ROS scavenging ability of synthesized compounds evaluated by DPPH assay method. Antioxidant activities of the synthesized compounds were determined for $500 \mu \mathrm{g} / \mathrm{mL}$ to $1.6 \mu \mathrm{g} / \mathrm{mL}$ also $\mathrm{IC}_{50}$ values were determined (Table-2). Compound 4 has remarkable activity $\left(\mathrm{IC}_{50}=259.65 \mu \mathrm{g} / \mathrm{mL}\right)$. 

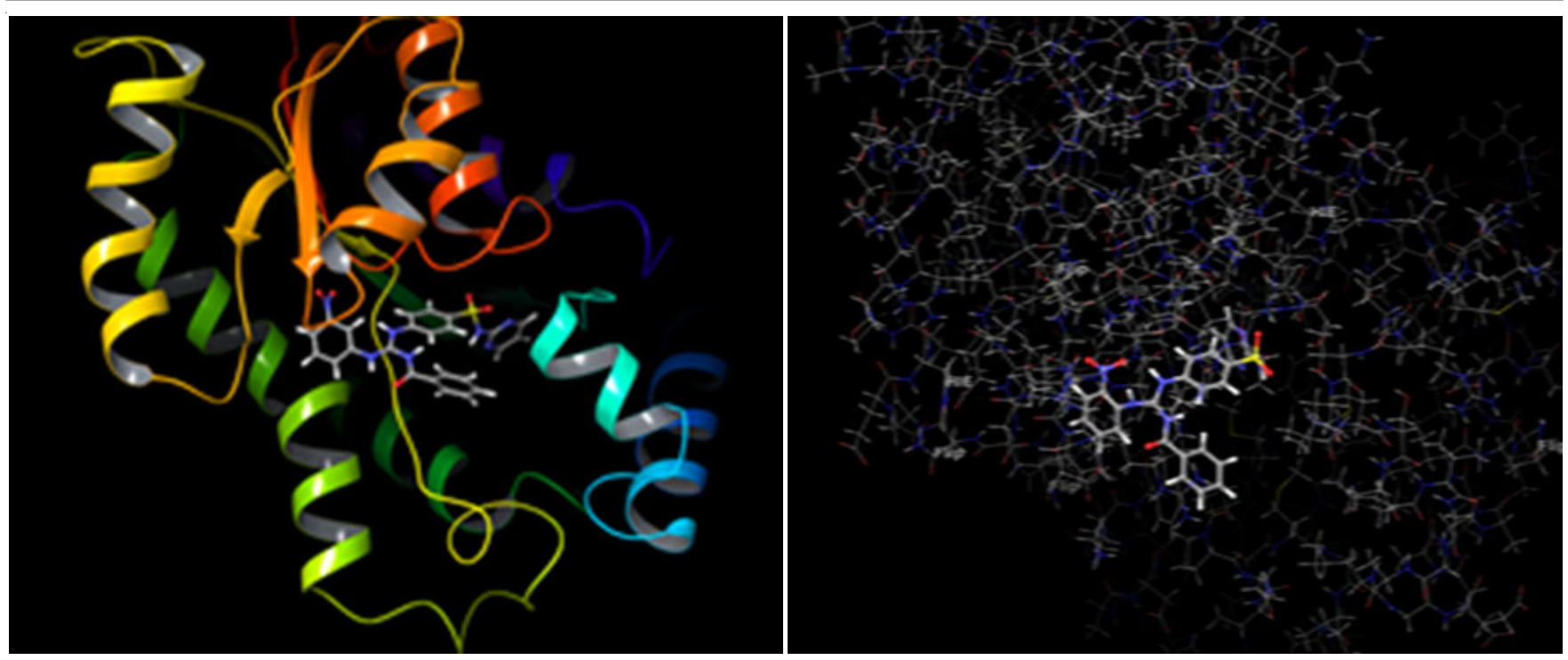

Fig. 1. Molecular docking study of compound 4

\begin{tabular}{cc}
\multicolumn{2}{c}{ TABLE-2 } \\
IC $_{50}$ VALUES OF ANTIOXIDANT ACTIVITY \\
\hline Compound No. & IC $_{50}$ values $(\mu \mathrm{g} / \mathrm{mL})$ \\
\hline 1 & 425.21 \\
2 & 377.23 \\
3 & 343.78 \\
4 & 259.65 \\
Ascorbic acid & 9.26 \\
\hline
\end{tabular}

\section{Conclusion}

An attempt has been made for the synthesis of sulfadiazine compounds with guanidinyl functionality. The synthesized compounds showed excellent antituberculosis activity, whose MIC values were upto $12.5 \mu \mathrm{g} / \mathrm{mL}$, which is also supported by molecular docking study. The resonance stabilization of guanidinyl group was mainly responsible for the observed activity and different groups on $N$-substituted phenyl rings of guanidinyl influence the activity. Some of the compounds also exhibited remarkable antioxidant activity.

\section{CONFLICT OF INTEREST}

The authors declare that there is no conflict of interests regarding the publication of this article.

\section{REFERENCES}

1. Y. Yamamoto and S. Kojima, Synthesis and Chemistry of Guanidine Derivatives: The Chemistry of Amidines and Imidates, John Wiley \& Sons Ltd., vol. 2 (1991)

2. D. Lednicer and L.A. Mitscher, eds., The Organic Chemistry of Drugs Synthesis; Wiley: New York, vol. II, (1980).
3. R.G.S. Berlinck, Fortschr. Chem. Org. Naturst., 66, 119 (1995); https://doi.org/10.1007/978-3-7091-9363-1 2.

4. K. Burgess, ed., Solid-Phase Organic Synthesis; John Wiley \& Sons: New York, USA (2000).

5. G.J. Durant, Chem. Soc. Rev., 14, 375 (1985); https://doi.org/10.1039/cs9851400375.

6. A. Echavarren, A. Galan, J.M. Lehn and J. De Mendoza, J. Am. Chem. Soc., 111, 4994 (1989); https://doi.org/10.1021/ja00195a071.

7. O. Kamoda, K. Anzai, J. Mizoguchi, M. Shiojiri, T. Yanagi, T. Nishino and S. Kamiya, Antimicrob. Agents Chemother, 50, 3062 (2006); https://doi.org/10.1128/AAC.00036-06.

8. M. Bhat and S.L. Belagali, Res. Chem. Intermed., 42, 6195 (2016); https://doi.org/10.1007/s11164-016-2454-6.

9. M. Bhat, S.L. Belagali and D.C. Shyamala, The Natural Products J., 7, 286 (2017);

https://doi.org/10.2174/2210315507666170530091940.

10. M. Bhat and S.L. Belagali, Anti-Infective Agents, 16, 1 (2018); https://doi.org/10.2174/2211352516666180425151720.

11. M. Varga, Textbook of Rabbit Medicine, Elsevier Health: UK, edn 2, pp. 137-177 (2014).

12. V.P. Arcangelo and A.M. Peterson, Pharmacotherapeutics for Advanced Practice: A Practical Approach, Lippincott Williams \& Wilkins, vol. 536, pp 959 (2006).

13. M.C.S. Lourenco, M.V.N. de Souza, A.C. Pinheiro, M. de L. Ferreira, R.S.B. Gonçalves, T.C.M. Nogueira and M.A. Peralta, ARKIVOC, 181 (2007); https://doi.org/10.3998/ark.5550190.0008.f18.

14. M.K. Raj, C. Balachandran, V. Duraipandiyan, P. Agastian, S. Ignacimuthu and A. Vijayakumar, Med. Chem. Res., 22, 3823 (2013); https://doi.org/10.1007/s00044-012-0393-3.

15. M. Fathimunnisa, H. Manikandan, K. Neelakandan, N. Rajendra Prasad, S. Selvanayagam and B. Sridhar, J. Mol. Struct., 1122, 205 (2016); https://doi.org/10.1016/j.molstruc.2016.06.012. 